\title{
Article \\ Correspondence between SOC1 Genotypes and Time of Endodormancy Break in Peach (Prunus persica L. Batsch) Cultivars
}

\author{
Júlia Halász ${ }^{1, *} \mathbb{0}$, Attila Hegedús ${ }^{1}$, Ildikó Karsai ${ }^{2}$, Ágnes Tósaki ${ }^{3}$ and László Szalay ${ }^{3}$ \\ 1 Department of Plant Biotechnology, Institute of Genetics and Biotechnology, Hungarian University of \\ Agriculture and Life Sciences, Ménesi út 44., 1118 Budapest, Hungary; hegedus.attila@uni-mate.hu \\ 2 ELKH Centre of Agricultural Research, Brunszvik u. 2., 2462 Martonvásár, Hungary; karsai.ildiko@atk.hu \\ 3 Department of Pomology, Institute of Horticultural Sciences, Hungarian University of Agriculture and Life \\ Sciences, Villányi út 35-43., 1118 Budapest, Hungary; agicaxd@gmail.com (Á.T.); \\ szalay.laszlo@uni-mate.hu (L.S.) \\ * Correspondence: Halasz.Julia@uni-mate.hu or genetics.prunus@gmail.com
}

Citation: Halász, J.; Hegedûs, A.;

Karsai, I.; Tósaki, Á.; Szalay, L.

Correspondence between SOC1

Genotypes and Time of

Endodormancy Break in Peach

(Prunus persica L. Batsch) Cultivars.

Agronomy 2021, 11, 1298. https://

doi.org/10.3390/agronomy11071298

Received: 25 May 2021

Accepted: 24 June 2021

Published: 26 June 2021

Publisher's Note: MDPI stays neutral with regard to jurisdictional claims in published maps and institutional affiliations.

Copyright: (c) 2021 by the authors. Licensee MDPI, Basel, Switzerland. This article is an open access article distributed under the terms and conditions of the Creative Commons Attribution (CC BY) license (https:/ / creativecommons.org/licenses/by/ $4.0 /)$.

\begin{abstract}
Knowledge of dormancy traits are important in peach breeding. Traditional method selection of seedlings takes a long time because of the juvenile period of plants; therefore, novel application of marker assisted selection methods are needed to accelerate this work. The aims of this study were to test the extent of variability in the PpSOC1 gene among 16 peach cultivars and to establish whether the variability of SOC1 can be used as a functional marker for the timing of endodormancy break based on a 14-year phenology evaluation covering nine consecutive phenology phases, from string stage to ripening. Based on an SSR motif of SOC1, three allele categories were detected: one peach cultivar was heterozygous (203/209), while five of the 15 homozygous cultivars carried a $203 \mathrm{bp}$ allele and the remainder were characterized with $218 \mathrm{bp}$. There were significant correlations between the PpSOC1 alleles and the various phenology phases, the strongest one being observed at the string stage, marking the end of endodormancy. At this stage, PpSOC1 explained $82.6 \%$ of the phenotypic variance; cultivars with the 203 allele reached the string stage 11.7 days earlier than those with $218 \mathrm{bp}$ allele. This finding makes the PpSOC1 screening a valuable method in breeding.
\end{abstract}

Keywords: Prunus persica; peach; endodormancy; SOC1; SSR

\section{Introduction}

Chilling requirement (CR) and the length of endodormancy of flower buds are important aspects in peach breeding. These traits determine the suitability of cultivars in different areas. In the northern hemisphere, cultivars with low chilling requirement are needed for southern sites, while cultivars with high CR will be suitable for northern production areas. Obviously, the situation is opposite in the southern hemisphere [1,2]. Many authors have dealt with the CR of peach cultivars and this parameter is often quoted in cultivar descriptions [3-14].

Endodormancy is a deep rest period of overwintering organs [15]. It is difficult to determine exactly the end of endodormancy based on establishing the chilling requirements of peach cultivars. It is usually estimated based on various quantitative parameters, such as forcing the flowers at room temperature or measuring the change in water content or weight of buds. Due to the different methodologies, the results are often controversial, and there are different chilling requirement data for various peach cultivars in different publications [2,4$6,9,16,17]$. The chilling requirement of cultivars depends on the geographical location of plantation as well, and not only on the inherited traits of genotypes $[1,11,18-23]$. Despite the uncertainties, it is a fact that there is great variability between peach cultivars in terms of chilling requirement and the rate of their flower bud development in winter. Chilling 
requirements were calculated as the amount of hours below $7{ }^{\circ} \mathrm{C}$ and ranged from 300 ('Desertgold') to 1000 ('Dixired') hours [6]. Based on the Utah Modell, Chilling Unit (CU) data of the widespread cultivars in practice were between 400 and $1200 \mathrm{CU}[5,9,13,14]$. There are peach genotypes with very low chilling requirement for cultivation in subtropical areas as well, for example 'Banquet' with 100 CU [11]. The Dynamic model counts the chilling portion (CP) accumulation with a special calculation method [7]. Variability of peach cultivars has been found to be between $19 \mathrm{CP}$ and $62 \mathrm{CP}$ [12], or $16.6 \mathrm{CP}$ and $75.1 \mathrm{CP}[14]$ in different locations and cultivar assortments. Sometimes the chilling portions are converted into chilling units for more comparability [13].

As a qualitative change, examination of microsporogenesis may help to determine the end of endodormancy. Previous studies on microsporogenesis of peach cultivars at different sites have placed the greatest emphasis on the tetrad state and the time of its formation [24]. Draczynski (1958) [25] studied pollen development in apricot, peach and almond cultivars close to the northern border of an economical production area and distinguished four stages of development (archesporium, pollen mother cell, tetrad and pollen). Based on pollen development, the cultivars were divided into four groups. Large differences in the formation of the tetrad stage were discovered between the genotypes. In all three species, there were those in which meiosis occurred extremely early, in late January or early February, while in others, this stage was observed only in March. Experiments in Italy showed that the endodormancy of peach comes to an end several weeks before the development of the tetrad stage [24]. The microsporogenesis process in various peach cultivars was characterized in Hungary as well, based on experiments repeated over several years at a number of locations [26,27]. Six development phases were identified in the microsporogenesis of peach cultivars: (1) archesporium, (2) string, (3) pollen mother cell, (4) tetrad, (5) microspore and (6) pollen grain. Nowadays, it is an accepted hypothesis that the string stage indicates the end of endodormancy. This is the signal that the chilling requirement of flower bud is satisfied, and the development of generative tissues will be continuing [28-30].

With traditional methods, it takes a long time to select for chilling requirements of hybrids as this is possible only when the juvenile period of the plants is ended, which requires six to eight years for peaches. New methods are needed to accelerate the selection. Various genetic and biochemical markers can help in this, greatly speeding up the selection process $[2,11]$.

Genetic variation affecting chilling or heat-dependent dormancy release still remains largely unknown, but recently a major QTL delaying blooming date in peach was mapped revealing a strict association with a genetic variant in a PETALOSA gene [31]. Until now, several genes and proteins were described to influence the bud dormancy in fruit tree species [32-34]. It was proved that MADS-box genes are involved in terminal bud dormancy of deciduous trees [35-37]. Expression analysis has indicated that peach $P p$ $D A M 5$ and $P p D A M 6$ are down-regulated at dormancy release or under prolonged lowtemperature treatment, suggesting their function in the chilling requirement of peach lateral buds through growth-inhibiting functions for bud break [38]. Apricot cultivars with higher chilling requirement and delayed flowering time showed higher expression levels of ParDAM5 and ParDAM6 toward the end of endodormancy [39]. It was clarified in Japanese apricot (Prunus mume Sieb. et Zucc.) that the dimer of PmDAM6 and PmSOC1 play a crucial role in the regulation of dormancy transition and blooming time [40] and protein interaction analysis demonstrated that PavDAM1 $/ 5$ could interact with PavSOC1 in sweet cherry [41]. SUPPRESSOR OF OVEREXPRESSION OF CONSTANS1 (SOC1) encodes a MADS-box protein which it is an integrator of six flowering pathways in Arabidopsis but is highly conserved among angiosperms, including both monocotyledons and dicotyledons [42]. In the peony tree (Paeonia suffruticosa), it was verified that PsSOC1 plays an evolutionarily conserved role in promoting flowering and dormancy release [43]. In the case of apricots (Prunus armeniaca L.), the variation at the ParSOC1 locus is associated with chilling requirements. The high correlation between chilling requirements and specific Par- 
SOC1 alleles provides a useful tool for breeding of low-chill requiring apricot cultivars [44] Marker-assisted selection (MAS) is a particularly reliable strategy for increasing selection efficiency, especially in fruit tree species with a long juvenile period by minimizing the period of trait evaluation at the orchard [45].

The aims of this study were (1) to test the extent of variability in the PpSOC1 gene among peach cultivars and (2) to establish whether the variability of $P p S O C 1$ can be used as a functional marker for the timing of endodormancy break in peaches. For this purpose, the $S O C 1$ allele types of 16 peach cultivars were determined and their associations with nine consecutive phenology phases from string stage to ripening were evaluated on the phenotypic data matrix of a 14-year long observation.

\section{Materials and Methods}

\subsection{Plant Material}

The plant material was available at the Experimental and Research Farm of Hungarian University of Agriculture and Life Sciences (Budapest, Hungary). A total of 16 peach cultivars (Table 1) were studied. The examination period of phenological traits covered 14 years between 2007 and 2020. The orchard was established in 2003, with a plant density of 1110 tree/ha. Each cultivar was propagated on a Prunus dulcis (Mill.) DA Webb seedling rootstock. A slender spindle growing system was applied with a standard integrated cropping technology, including fertilization, drip irrigation, regular pruning and hand fruit thinning. Three trees of each cultivar were available for the study.

Table 1. List of the peach cultivars included in the study with their PpSOC1 genotypes and corresponding data about the end of endodormancy and chill portions according to the dynamic model.

\begin{tabular}{|c|c|c|c|c|c|c|c|c|}
\hline \multirow[t]{2}{*}{ Cultivar } & \multirow[t]{2}{*}{ Pedigree * } & \multirow[t]{2}{*}{ Origin } & \multirow[t]{2}{*}{ SOC1 Genotype } & \multicolumn{3}{|c|}{ End of Endodormancy ${ }^{1}$} & \multicolumn{2}{|c|}{$\begin{array}{c}\text { Chilling } \\
\text { Requirement }\end{array}$} \\
\hline & & & & Date & Days from 1 January & Sign. Level ${ }^{2}$ & $\mathrm{CP}$ & $\mathrm{CV} \%$ \\
\hline Kraprim & unknown & USA & $203 / 203$ & 22 January & 21.6 & a & 64 & 4.5 \\
\hline Rich Lady & $\begin{array}{c}\text { open pollinated seedling } \\
\text { of Amparo Peach }\end{array}$ & USA & $203 / 203$ & 22 January & 21.6 & a & 64 & 4.5 \\
\hline Venus & $\begin{array}{l}\text { Stark Redgold } \\
\times \text { Flamekist }\end{array}$ & Italy & $203 / 203$ & 22 January & 21.6 & a & 64 & 4.5 \\
\hline Springtime & $\begin{array}{l}\text { (Lukens Honey } \times \text { July } \\
\text { Elberta) } \times \text { Robin }\end{array}$ & USA & $203 / 203$ & 22 January & 21.6 & a & 64 & 4.5 \\
\hline Red June & $\begin{array}{l}\text { F2 hybrid of Le Grand } \times \\
\text { July Elberta }\end{array}$ & USA & $203 / 203$ & 24 January & 24.0 & a & 65 & 3.9 \\
\hline Spring Lady & unknown & USA & $203 / 209$ & 26 January & 25.8 & $\mathrm{ab}$ & 66 & 4.3 \\
\hline Redhaven & Halehaven $\times$ Kalhaven & USA & $218 / 218$ & 29 January & 29.4 & $\mathrm{~b}$ & 68 & 4.8 \\
\hline Jerseyland & $\begin{array}{c}\text { of J.H. Hale } \times \text { (Slappey } \times \\
\text { Admiral Dewey) }\end{array}$ & USA & $218 / 218$ & 31 January & 31.2 & $\mathrm{~b}$ & 71 & 7.0 \\
\hline Elberta & $\begin{array}{c}\text { open pollinated seedling } \\
\text { of Chinese Cling } \\
\text { open pollinated seedling }\end{array}$ & USA & $218 / 218$ & 2 February & 33.1 & $\mathrm{bc}$ & 71 & 3.7 \\
\hline Babygold 7 & $\begin{array}{l}\text { of }(\text { Lemon Free } \times \text { P.I. } \\
\text { 35201) } \times \text { J.H. Hale } \\
\times \text { Goldfinch }\end{array}$ & USA & $218 / 218$ & 2 February & 33.1 & $\mathrm{bc}$ & 71 & 3.7 \\
\hline Michelini & $\begin{array}{l}\text { unknown seedling } \\
\text { from Italy }\end{array}$ & Italy & $218 / 218$ & 4 February & 34.6 & $\mathrm{bc}$ & 73 & 4.8 \\
\hline Champion & $\begin{array}{l}\text { Oldmixon free } \times \\
\text { Early York }\end{array}$ & USA & $218 / 218$ & 4 February & 34.6 & $\mathrm{bc}$ & 73 & 4.8 \\
\hline Piroska & Hungarian selection & Hungary & $218 / 218$ & 5 February & 36.4 & c & 74 & 5.0 \\
\hline Zsoltüj & unknown & Russia & $218 / 218$ & 7 February & 38.2 & c & 75 & 5.9 \\
\hline Cresthaven & $\begin{array}{c}\text { Kalhaven } \times \text { South } \\
\text { Haven } 309\end{array}$ & USA & $218 / 218$ & 7 February & 38.2 & c & 75 & 5.9 \\
\hline
\end{tabular}

${ }^{1}$ evaluation based on the microsporogenesis observation, averages of 14 years are presented. ${ }^{2}$ values followed by the same letter are not significantly different at $p$-value $=0.05$ level. ${ }^{*}[46]$.

\subsection{DNA Extraction, PCR Amplification and Cloning}

Genomic DNA extraction from leaves was carried out using the DNeasy Plant Mini Kit (QIAGEN, Hilden, Germany) according to the instructions. The quantity and quality of DNA were analysed by NanoDrop ND-1000 spectrophotometer (Bio-Science, Budapest, Hungary). PCR analysis in a reaction volume of $20 \mu \mathrm{L}$ contained $20-40 \mathrm{ng}$ of genomic 
DNA, 10X DreamTaq Green Buffer (Fermentas, Szeged, Hungary) with final concentration of $4.5 \mathrm{mM} \mathrm{MgCl} 2,0.2 \mathrm{mM}$ of dNTPs, $0.2 \mu \mathrm{M}$ of the $S O C 1$ specific primers (AglA1- 5 forward and AglA1-CT reverse, [44]) and $0.75 \mathrm{U}$ of DreamTaq DNA Polymerase (Fermentas). The PCR protocol was used as described by Trainin et al. (2013) [44]. The PCR products were separated on $1 \%$ TAE agarose gels at $80 \mathrm{~V}$ for $1 \mathrm{~h}$ and DNA bands were stained with ethidium bromide. In the case of three cultivars, PCR products were cloned into the pTZ57R/T plasmid vector using the InsTAclone PCR Cloning Kit (Thermo Scientific, Waltham, MA, USA) and sequenced by ABI 3500 XL Genetic Analyzer (Applied Biosystems, Foster City, CA, USA).

\subsection{Evaluation of the Various Phenological Stages}

A detailed 14-year long dataset recorded between 2007 and 2020 is available for the 16 peach cultivars covering the process of floral bud development, blooming and the ripening period, as well. For determining the floral developmental stages during dormancy, samples consisting of five long shoots from the middle height of the tree canopy of each cultivar were collected from the beginning of December weekly. In the laboratory, anthers were removed from the flower buds of the middle section of long shoots (10-12 flower buds per cultivar). Anthers stained with carminic acetic acid were examined under Olympus BX41 microscope (Olympus Corporation, Tokyo, Japan) with 200x and 600x magnification. The following consecutive developmental stages were determined: string, pollen mother cell, tetrad, microspore and pollen [27]. The transition from one phenological phase to another is always a gradual, time-consuming process. The start of a given developmental stage of a particular genotype during dormancy was considered where $50 \%$ of the previous and $50 \%$ of the next stage were visible under microscope [26-30]. Of the later developmental stages, the start and the end of blooming and the start and end of ripening were recorded at the orchard with the standard, established method [47], where three trees of each cultivar were grown under similar conditions and orchard management.

\subsection{Determination of Chilling Requirements}

Hourly air temperatures were determined by a PT100 1/3 Class B temperature sensor with $\pm 1{ }^{\circ} \mathrm{C}$ accuracy as implemented in the iMETOS ${ }^{\circledR}$ IMT200 (Pessl Instruments, Weiz, Austria). The instrument was in an open area within $400 \mathrm{~m}$ of the orchard. The amount of cold received by the plants was quantified using the chill portions of the Dynamic model [7]. The date of breaking endodormancy was determined by the appearance of the string developmental stage of anthers.

\subsection{Data Analysis}

For fragment length analysis, the PCR products amplified by fluorescently labelled (6-FAM) forward primer were run in an automated sequencer ABI PRISM 3100 Genetic Analyzer (Applied Biosystems, Foster City, CA, USA). For data analysis, ABI Peak Scanner 1.0 software and GS500 LIZ size standard were used (Applied Biosystems, Foster City, CA, USA). The identified PpSOC1 sequences were used as a query sequence for MegaBLAST analysis [48]. An alignment of 7 Prunus SOC1 sequences was carried out using the CLUSTAL W program [49] in MEGA5.1 [50] and the alignment was manually curated. The alignments are presented using BioEdit v.7.0.9.0 [51].

For the various phenology parameters, the statistical analyses were carried out using the STATISTICA software package, version 13.5.0.17 (TIBCO Software Inc. Palo Alto, USA). In addition to two-way analysis of variance (ANOVA), mixed linear model (REML) was used for estimating the variance components $\left(\sigma^{2}\right)$ of cultivars and years in explaining the phenotypic variance at the various floral developmental stages. Regression analyses were carried out between the marker allele types and each individual developmental phase. In order to better demonstrate the association between marker alleles and the developmental processes, principal component analysis (PCA) was carried out on the data matrix of 
16 peach cultivars $\times 9$ developmental phases averaged over the 14 years as the genotypic effects were a highly significant component at each developmental stage.

\section{Results}

\subsection{PpSOC1 Genotypes of Peach Cultivars}

Trainin et al. (2013) [44] revealed that in the case of apricot (P. armeniaca L.), the SSR motif in the ParSOC1 5'UTR is an allelic marker for the ParSOC1 gene. Their analyses showed significant linkage between the presence of two alleles and chilling requirements (CR). Different alleles were named according to their length in bp in the given microsatellite region. Our study was performed to check its utility and reliability in case of peach cultivars. The SOC1 specific forward AglA1-5 primer [44] was fluorescently labelled and used for PCR analysis of 16 peach cultivars. The PCR products were sized precisely on a capillary sequencer. Fragment length analysis of peach cultivars with varied origin and phenotype showed the presence of only three different allele sizes: $203 \mathrm{bp}, 209 \mathrm{bp}$ and $218 \mathrm{bp}$. According to the chromatograms, three distinct genotypes were recorded (Table 1): five cultivars were homozygous for the 203 allele (203/203); one cultivar was heterozygous carrying the 203 and 209 alleles (203/209); while 10 cultivars were homozygous for the 218 allele (218/218). These three alleles were cloned and sequenced from 'Springtime' (203), 'Spring Lady' (209) and 'Redhaven' (218) cultivars. After homology searches in the GenBank database, four other Prunus sequences were found. The 203 allele from 'Springtime' was identical with the reference allele (XM020557125.1) of 'Lovell' peach cultivar, while the alignment of the nucleotide sequences showed some alterations (indels and base substitutions) in the available cherry (P. avium XM021970057.1), apricot (P. armeniaca FJ472817.1) and Japanese apricot (P. mume JF806632.1) alleles (Figure 1). The 203 allele contains CT repeats in 18 copies, 209 allele in 21 copies, while 218 allele shows 25 copies and an extra thymine.

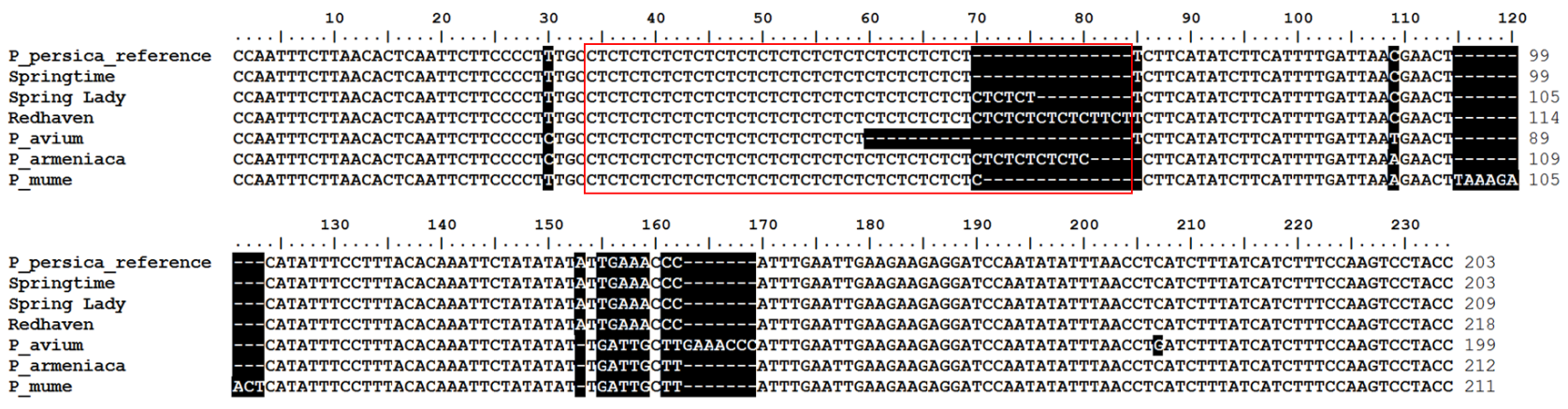

Figure 1. Alignment of the 5'UTR in SOC1 sequences of peach (P. persica XM020557125.1), cherry (P. avium XM021970057.1), apricot (P. armeniaca FJ472817.1) and Japanese apricot (P. mume JF806632.1) genotypes. Sequence alterations are shown in black boxes; the framed region is a CT dinucleotide microsatellite (SSR). Partial sequences from Springtime, Spring Lady and Redhaven were determined in this study.

\subsection{Peach Phenology and Its Association with the Allele Variation in PpSOC1 Locus}

Both genotype and year were significant components in determining the phenotypic variance throughout the phenology processes; however, their roles in explaining the variance changed with the developmental phases (Table 2). In general, during microsporogenesis and flowering, the year effect was more pronounced, and the opposite was true for ripening. Within this general tendency, there was a marked shift in the roles of genotype vs. year effects over the stages of microsporogenesis. At the string stage, which marks the end of endodormancy, genotype explained $21.7 \%$ of the phenotypic variance, while it was $77.1 \%$ for the year effect. As microsporogenesis processed, the role of genotype gradually decreased and that of year gradually increased. By the time of the start of blooming, their values were $4.8 \%$ and $93.7 \%$, respectively. 
Table 2. Variance analysis of various peach developmental stages and their association with the allele type of SOC1 gene.

\begin{tabular}{|c|c|c|c|c|c|c|c|}
\hline \multirow{2}{*}{ Phenology Stages } & \multicolumn{2}{|c|}{$\begin{array}{c}\% \text { of Variance } \\
\text { Explained }\left(\% \text { of } \sigma^{2}\right)\end{array}$} & \multicolumn{2}{|c|}{$\begin{array}{l}\text { SOC1 Marker } \\
\text { Regression }\end{array}$} & \multicolumn{3}{|c|}{$\begin{array}{l}\text { Average Values in Days a of the SOC1 } \\
\text { Marker Allele Groups of Peach Cultivars }\end{array}$} \\
\hline & $\underset{\text { (16) }}{\text { Genotype }}$ & $\begin{array}{l}\text { Year } \\
\text { (14) }\end{array}$ & $r^{2}$ & $p$-Level & $\begin{array}{l}203^{\mathrm{b}} \\
(n=5)\end{array}$ & $\begin{array}{c}218 \\
(n=10)\end{array}$ & Difference $^{\mathrm{d}}$ \\
\hline String & $21.7 * * *$ & $77.1^{* * *}$ & 0.826 & $11.1 \times 10^{-6}$ & 22.1 & 33.8 & $11.7^{* * *}$ \\
\hline Pollen mother cell & $19.9^{* * *}$ & $78.5 * * *$ & 0.829 & $9.9 \times 10^{-7}$ & 31.2 & 41.8 & $11.6^{* * *}$ \\
\hline Tetrad & $18.2^{* * *}$ & $79.4^{* * *}$ & 0.829 & $9.5 \times 10^{-7}$ & 39.0 & 49.7 & $10.7^{* * *}$ \\
\hline Microspore & $18.0^{* * *}$ & $79.8^{* * *}$ & 0.826 & $1.1 \times 10^{-6}$ & 47.9 & 58.3 & $10.4^{* * *}$ \\
\hline Pollen & $11.1^{* * *}$ & $88.5^{* * *}$ & 0.813 & $1.8 \times 10^{-6}$ & 78.2 & 83.4 & $5.2 * * *$ \\
\hline Start of blooming & $4.8^{* * *}$ & $93.7 * * *$ & 0.772 & $7.5 \times 10^{-6}$ & 92.1 & 95.5 & $3.4^{* * *}$ \\
\hline End of blooming & $5.5^{* * *}$ & $92.9 * * *$ & 0.752 & $1.4 \times 10^{-5}$ & 105.0 & 108.0 & $3.0^{* * *}$ \\
\hline Start of ripening & $97.9^{* * *}$ & $1.9 * * *$ & 0.307 & 0.026 & 192.7 & 221.5 & $28.8 *$ \\
\hline End of ripening & $98.0^{* * *}$ & $1.8^{* * *}$ & 0.301 & 0.028 & 200.8 & 229.5 & $28.7 *$ \\
\hline
\end{tabular}

The marker regression analyses revealed the presence of significant correlations between the PpSOC1 alleles and the various phenological phases (Table 2). The correlation was the strongest in the case of microsporogenesis, from the string stage to pollen formation, where $81.3-82.9 \%$ of the variation were explained by SOC1 genotypes. The difference in days from 1 January (DFFJ) between the two homozygous groups of cultivars was the highest at the string stage that was reached 11.7 days earlier (averaged over 14 years) by the cultivars carrying the 203 allele than the group carrying the 218 allele. The 14-year averaged dates of the cultivars reaching the string stage are listed in Table 1 . The observed cultivars have been classified into three groups based on the date reaching the end of endodormancy. The earliest group contained five cultivars ('Kraprim', 'Rich Lady', 'Venus', 'Springtime', 'Red June'), which all carried the 203 allele of PpSOC1. The string stage of 'Spring Lady' with the 203/209 allele type was close to the earliest group. All the other cultivars carried the 218 allele type. Based on their string stage, they could be divided into three groups: the mid-early group included three cultivars ('Redhaven', 'Early Redhaven' and 'Jerseyland'), four cultivars ('Elberta', 'Babygold 7', 'Michelini' and 'Champion') were mid-late, while three cultivars ('Piroska', 'Zsoltuij' and 'Cresthaven') belonged to the latest group. As the micropsorogenesis progressed, the difference between the two allele groups of 203 vs. 218 gradually decreased to 10.4 days at the microspore stage, then dropped to 5.2 days at the pollen stage. During blooming, the SOC1 alleles explained $75.2 \%$ and $77.2 \%$ of the variance, and the difference between the two allele groups was only 3.0-3.4 days. All these correlations were significant $(p$-value $<0.001)$, irrespective of the observed decrease in the difference between the two allele groups. chill portions were also determined in four dormancy seasons according to the dynamic model and values ranged between 64 and $75 \mathrm{CP}$. The $\mathrm{CV} \%$ values were lower than $6 \%$ and chill portions showed a close correlation with PpSOC1 genotypes.

It is interesting to note that the PpSOC1 alleles also showed correlations with the ripening time, though this correlation was only significant at $p$-value $=0.05$ level, and it explained around $30 \%$ of the phenotypic variance (Table 2). Again, the average ripening time of the cultivars with the 203 PpSOC1 allele was 28.8 days earlier, as compared to the 218-bp allele group.

PCA was carried out on the data matrix of 16 peach cultivars $\times 9$ developmental phases (each averaged over the 14-year observations), in which the first two factors had an Eigen value higher than 1 (Figure 2). Factor 1 was responsible for explaining $88.1 \%$ of the groupings, and it showed very strong correlations with the string stage $\left(r\right.$-value $\left.=-0.98^{* * *}\right)$ also including the timing of the following microsporogenesis and blooming stages. The two groups of peach cultivars with the PpSOC1 alleles of 203 and 218 were clearly separated along Factor 1. Factor 2 explained $10.7 \%$ of the groupings and showed significant correlations both with the microsporgenesis-blooming stages $(r$-value $=-0.72 * *)$ and with 
the ripening time $\left(r\right.$-value $\left.=0.69^{* *}\right)$. It further separated the peach cultivars within each endodormancy group based on the ratio of days elapsed to ripening/days elapsed to string stage. Thus, within the early microsporogenesis group with the 203 allele (the average between the string stage and the start of ripening being 7.8), 'Red June' and 'Venus' were placed further apart along the $y$-axis, due to their relatively late ripening time resulting in ratios of 9.3 and 10.8, respectively. Similarly, 'Piroska' of the late microsporgenesis group was an outlier with its 5.3 ratio compared to the group mean values of 6.1-7.4. 'Spring lady', the only heterozygous cultivar (203/209) was again placed between the early 203 and the mid-early 218 groups.

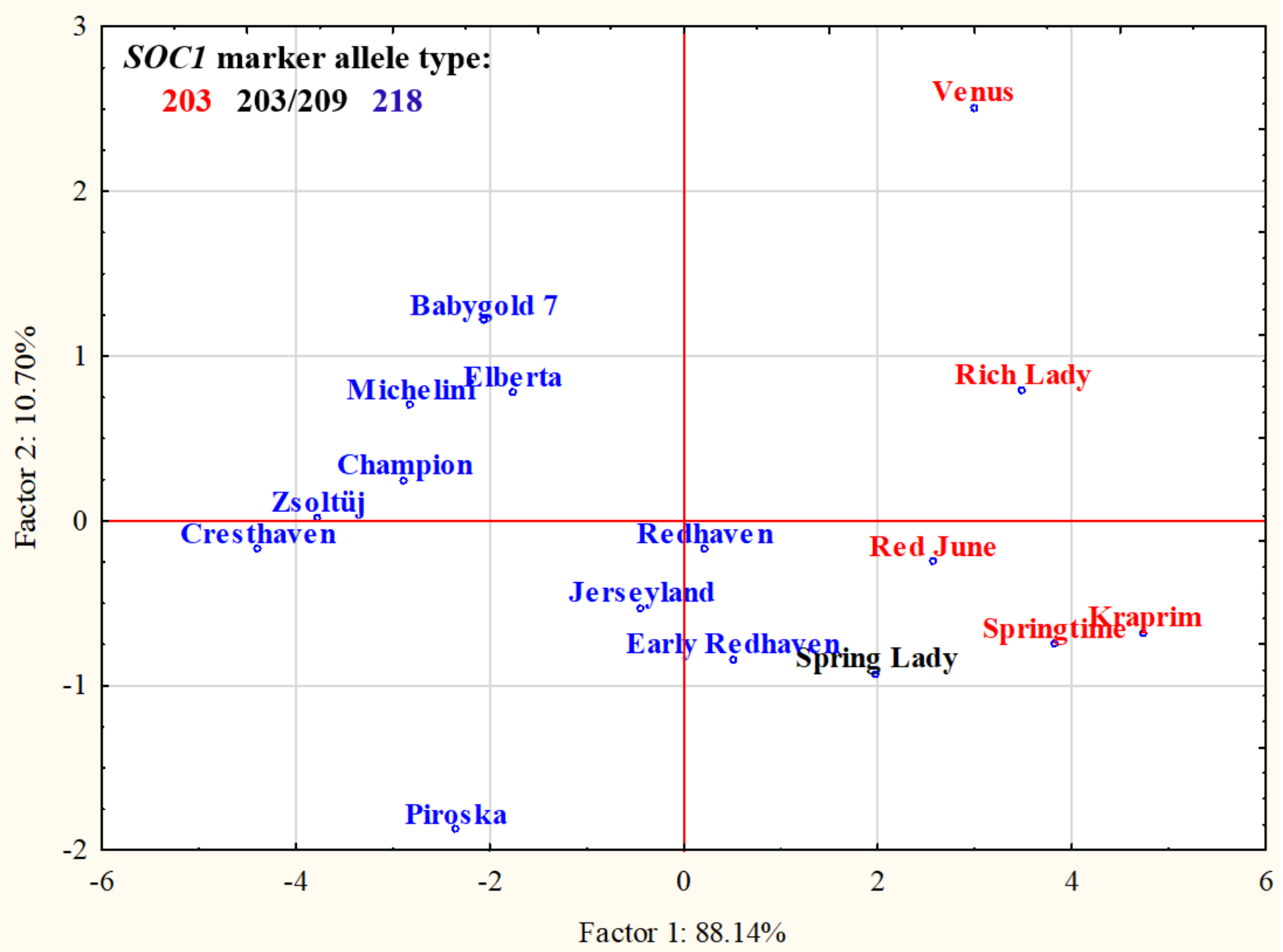

Figure 2. Grouping of the peach cultivars and its association with the $S O C 1$ marker allele types based on the principal component analysis (PCA) carried out on the matrix of 16 cultivars and nine developmental phases from string stage to end of ripening.

\section{Discussion}

To determine the chilling requirement of peach cultivars, it is important to specify the end of endodormancy of flower buds as accurately as possible $[2,9,11,13,14]$. Flower bud development during dormancy can be followed by monitoring the microsporogenesis stages. Differentiation of archesporium tissue in anthers results in forming of pollen mother cells and pollen grains. String stage can be taken as the end of endodormancy, and the beginning point of ecodormancy. This stage is the signal that the chilling requirement of the flower bud is satisfied [26-30]. In our study, the CP values of peach cultivars were higher than those reported previously for 'Spring Lady' and especially for 'Rich Lady' [16,52]. 
This might be explained by the regions compared as the reported values are from Argentina and Spain, much warmer regions compared to Hungary. Such results fit those that lower $\mathrm{CR}$ values were measured in warmer seasons than in colder ones [53]. In the southern part of the Czech Republic, the microsporogenesis of 16 peach cultivars was studied for three years. The end of endodormancy was between mid-January and mid-February, depending on the genotype in this study [54]. Our results proved that there is a large variance between the years in the end of endodormancy; averaged over the 16 peach cultivars, there was a 33-day difference among the earliest and latest dates during the period of 14 years with the interval occurring between mid-January and mid-February under the Hungarian conditions. In addition to the year effect, however, the genotype effect was also a significant source of the variance with a 12-to-25-day difference between the earliest and latest peach cultivars depending on the year. Castede et al. (2014) [55] in sweet cherry (P. avium) genotypes identified chilling requirement as the high heritable component of flowering date as compared to the heat requirements. During a three-year period, apricot cultivars were ranked in terms of the schedule of microsporogenesis in Hungary. The same order was observed every year, and this order can be considered as an indication of the crop safety of the varieties [56]. Despite large differences between the genotypes in different years, the order of peach genotypes reaching a specific developmental stage was unchanged in each of the studied years. The breeding strategy for the length of endodormancy depends on the location of the production zones. In cold growing regions such as Hungary, genotypes with higher CR are of great importance as they can match local climatic conditions to avoid crop losses due to late frosts $[1,2,11]$. However, in warm production areas, insufficient chilling leads to poor bud break that is going to be further aggravated due to global warming. Here the aim is to breed cultivars with the lowest possible chilling requirements [11,57]. In each case, the CR and dormancy traits are in the focus of peach breeding programs. Because of the long juvenile period of peach, new marker assisted selection methods are needed to accelerate this work. One of the promising tools can be the detection of the allelic variance in the SOC1 gene, which was already proven useful in apricot [44].

Until now, the SSR region of SOC1 gene was analysed only in apricot [44]. The ParSOC1 gene (Prunus armeniaca SOC1) belongs to MIKC MADS-box genes, shown to be involved in bud dormancy [40]. In the Perfection $\times$ A.1740 mapping population, the gene was positioned in the linkage group 2 near a QTL region that plays a role in determining flowering time [58]. The SSR element was located in position of 240-bp upstream to the ATG start codon and appeared in variable lengths in several cultivars. Altogether, 13 different alleles were found in 48 cultivars, showing a high proportion of heterozygotes [44]. Compared to this, only three alleles were identified in peach cultivars and only one heterozygous genotype was recorded while 15 cultivars were homozygous. This fact can be the consequence of the smaller sample size (16 genotyped peach cultivars in contrast with the 48 apricot cultivars). However, it might be likely that the genetic diversity contained within this set of 16 peach cultivars is lower than the one present in the set of 48 apricot cultivars. Although the ancestry of the studied cultivars does not seem to have many shared parents (Table 1), domestication bottleneck is well known in peach germplasm with a few varieties providing the genetic foundation of the modern western cultivars [59]. Furthermore, Prunus species are self-incompatible, a trait controlled by the $S$-allele system to maintain genetic variability over generations. The only exception in the genus is peach with self-fertility due to several mutations that had arisen before domestication [60]. As a result, the peach genome is characterized by a high degree of homozygosity and genetic variability is very low compared to other Prunus species [61,62].

Trainin et al. (2013) [44] supposed that the polymorph SSR region in the $5^{\prime}$ UTR could influence the function of ParSOC1 through an effect on the stability of transcribed mRNA molecule. It is possible that the SSR site is a target for proteins that regulate mRNA stability. Immink et al. (2012) [63] showed that several MADS proteins bind to the $5^{\prime}$ UTR of SOC1 in Arabidopsis. The SSR motif is a part of the ParSOC1 promoter playing a role in its transcriptional regulation. 
In heterozygous apricot cultivars, it was proved that both ParSOC1 alleles are transcribed. The 215 allele is associated with low chilling requirements, while the 262 allele is associated with high chilling requirements [44]. Peach alleles also appeared in similar size ranges (203 bp, $209 \mathrm{bp}$ and $218 \mathrm{bp}$ ). Despite the low number of allele variants in peach, we identified highly significant associations between the SOC1 allele composition and the timing of microsporogenesis and blooming. This association was the strongest at the string stage, which marks the end of endodormancy. Cultivars could be grouped into three groups based on their chilling requirement: the first five ('Kraprim', 'Rich Lady', 'Venus', 'Springtime' and 'Red June') with the shortest endodormancy period proved to be homozygous for the 203 allele. The only heterozygous 203/209 genotype, 'Spring Lady', was close to this early group. While 10 cultivars with the homozygous 218/218 genotype ('Redhaven', 'Early Redhaven', 'Jerseyland', 'Elberta', 'Babygold 7', 'Michelini', 'Champion', 'Piroska', 'Zsoltuij' and 'Cresthaven') were intermediate or late in the length of endodormancy. These results underline the fact that the phenomenon observed in the apricot and the presence of certain alleles linked to the amount of cold demand is also present in peach, though to a smaller extent due to the lower number of alleles. Just as in the case of apricot, the shorter allele was accompanied with lower chilling requirement. Although the PpSOC1 variation is not sufficient to differentiate peach genotypes with medium to late microsporogenesis, our results with the 203-allele type are consistent across years and genotypes in that this allele effectively detects those genotypes with small chilling portion requirements resulting in the early end of endodormancy. This finding makes PpSOC1 screening a valuable method in the breeding of new peach cultivars that are suitable for specific peach production areas. The cold growing zones applying a negative selection against the 203-allele type of SOC1 gene in young seedlings of segregating populations makes it possible to safely remove those individuals that represent a major risk of suffering serious frost damage during early spring because of their precocious start of floral bud development. Likewise, in warmer zones, a positive selection for the 203 PpSOC1-allele ensures the identification of early genotypes with low chilling requirements. Although the associations between the PpSOC1 alleles and ripening time were also significant, albeit to a much smaller extent, and a wide range of ripening times could be detected within each group, it may not rule out the possibility of using this marker for the selection of this trait.

The DNA sequences of three different alleles were compared with the homologous Prunus sequences in NCBI database. It was verified that the difference in length of fragments is caused by the variable number of repeats of the $\mathrm{CT}$ dinucleotide motif as in case of apricot [44]: the 203 alleles in 18 copies, the 209 alleles in 21 copies and the 218 alleles in 25 copies with an extra thymine. There are 13 repeats in sweet cherry and 18 repeats in Japanese apricot. However only one genotype was tested and sequenced in these species, and thus, intraspecific variability is unknown for other Prunus species.

Our results showed that detected alterations in the SSR region of SOC1 gene could be used not only in apricot but also in peach as a molecular diagnostic assay for breeding cultivars with different chilling requirements.

Author Contributions: All authors contributed to the study conception and design. Material preparation, data collection and analysis were performed by J.H., L.S. and Á.T., J.H., Á.T. and L.S. conducted the experiments. A.H., L.S. and I.K. interpreted the data. Statistical analysis was carried out by I.K. and A.H. The first draft of the manuscript was written by J.H. and L.S. and all authors commented on previous versions of the manuscript. All authors have read and agreed to the published version of the manuscript.

Funding: This research was supported by the NKFI K 128874 project and the Ministry for Innovation and Technology within the framework of the Thematic Excellence Programme 2020-Institutional Excellence Subprogram (TKP2020-IKA-12) for research on plant breeding and plant protection.

Data Availability Statement: The datasets generated during and/or analysed during the current study are available from the corresponding author on reasonable request. DNA sequences are available in NCBI Genbank. 
Conflicts of Interest: The authors declare no conflict of interest.

\section{References}

1. Lang, G.A. (Ed.) Plant Dormancy: Physiology, Biochemistry and Molecular Biology; CAB International: Wallington, UK, 1996.

2. Hancock, J.F.; Scorza, R.; Lobos, G.A. Peaches. In Temperate Fruit Crop Breeding; Hancock, J.F., Ed.; Springer Science + Business Media B.V.: Dordrecht, The Netherlands, 2008; pp. 265-298.

3. Weinberger, J.H. Chilling requirements of peach varieties. Proc. Am. Soc. Hortic. Sci. 1950, 56, 122-128.

4. Weinberger, J.H. Some temperature relations in natural breaking of the rest of peach flower buds in the San Joaquin Valley, California. Proc. Am. Soc. Hortic. Sci. 1967, 91, 84-89.

5. Richardson, E.A.; Seeley, S.D.; Walker, D.R. A model for estimating the completion of rest for 'Redhaven' and 'Elberta' peach trees. HortScience 1974, 9, 331-332.

6. Childers, N.F. Modern Fruit Science; Hort Public Gainesville: Gainesville, FL, USA, 1983; 538p.

7. Fishman, S.; Erez, A.; Couvillon, G.A. The temperature dependence of dormancy breaking in plants: Mathematical analysis of a two-step model involving a cooperative transition. J. Theor. Biol. 1987, 124, 473-483. [CrossRef]

8. Erez, A.; Fishman, S. The dynamic model for chilling evaluation in peach buds. Acta Hortic. 1998, 465, 507-510. [CrossRef]

9. Okie, W.R. Handbook of Peach and Nectarine Varieties; United States Department of Agriculture: Washington, DC, USA, 1998.

10. Erez, A. (Ed.) Bud dormancy; phenomenon, problems and solutions in the tropics and subtropics. In Temperate Fruit Crops in Warm Climates; Springer: Dordrecht, The Netherlands; Kluwer Academic: Dordrecht, The Netherlands, 2000 ; pp. 17-48.

11. Layne, D.R.; Bassi, D. The Peach; CAB International: Wallington, UK, 2008.

12. Ghrab, M.; Ben Mimoun, M.; Masmoudi, M.M.; Ben Mechlia, N. Chilling trends in a warm production area and their impact on flowering and fruiting of peach trees. Sci. Hortic. 2014, 178, 87-94. [CrossRef]

13. Milech, C.G.; Dini, M.; Scariotto, S.; Santos, J.; Herter, F.G.; Raseira, M.C.B. Chilling requirement of ten peach cultivars estimated by different methods. J. Exp. Agric. Int. 2018, 20,1-9. [CrossRef]

14. Kwon, J.H.; Nam, E.Y.; Yun, S.K.; Kim, S.J.; Song, S.Y.; Lee, Y.H.; Hwang, K.D. Chilling and heat requirement of peach cultivars and changes in chilling accumulation spectrums based on 100-year records in Republic of Korea. Agric. For. Meteorol. 2020, 288, 108009. [CrossRef]

15. Lang, G.A.; Early, J.D.; Martin, G.C.; Darnell, R.L. Endo-, para-, and ecodormancy: Physiological terminology and classification for dormancy research. HortScience 1987, 22, 371-377.

16. Fadón, E.; Fernandez, E.; Behn, H.; Luedeling, E. A conceptual framework for winter dormancy in deciduous trees. Agronomy 2020, 10, 241. [CrossRef]

17. Fadón, E.; Herrera, S.; Guerrero, B.I.; Guerra, M.E.; Rodrigo, J. Chilling and heat requirements of temperate stone fruit trees (Prunus sp). Agronomy 2020, 10, 409. [CrossRef]

18. Faust, M.; Erez, A.; Rowland, L.J.; Wang, S.Y.; Norman, H.A. Bud dormancy in perennial fruit trees: Phisiological basis for dormancy induction, maintance and release. HortScience 1997, 32, 623-629. [CrossRef]

19. Dennis, F.G., Jr. Problems in standardizing models for evaluating the chilling requirements for the breaking of dormancy in buds of woody plants. HortScience 2003, 38, 347-350. [CrossRef]

20. Tromp, J. Dormancy. In Fundamentals of Temperate Zone Tree Fruit Production; Tromp, J., Webster, A.D., Wertheim, S.J., Eds.; Backhuys Publishers: Leiden, The Netherlands, 2005; pp. 65-73.

21. Bartolini, S.; Piccolo, E.L.; Remorini, D. Different summer and autumn water deficit affect the floral differentiation and flower bud growth in apricot (Prunus armeniaca L.). Agronomy 2020, 10, 914. [CrossRef]

22. Bartolini, S.; Massai, R.; Viti, R. The influence of autumn-winter temperatures on endodormancy release and blooming performance of apricot (Prunus armeniaca L.) in central Italy based on long-term observations. J. Hortic. Sci. Biotechnol. 2020, 95, 794-803. [CrossRef]

23. Fernandez, E.; Whitney, C.; Cuneo, I.F.; Luedeling, E. Prospects of decreasing winter chill in Chile throughout the 21st century. Clim. Chang. 2020, 159, 423-439. [CrossRef]

24. Ramina, A.; Colauzzi, M.; Masia, A.; Pitacco, A.; Caruso, T.; Messina, R.; Scarabelli, G. Hormonal and climatological aspects of dormancy in peach buds. Acta Hort 1995, 395, 35-46. [CrossRef]

25. Draczynski, M. Die zeitliche Verlauf der Pollendifferenzierung bei Mandel, Pfirsich und Aprikose und der Einfluss der Knospentemperaturen auf diese Vorgänge. Gartenbauwissenschaft 1958, 23, 327-341.

26. Szalay, L.; Timon, B.; Szabó, Z.; Papp, J. Microsporogenesis of peach (Prunus persica L. Batsch) varieties. Int. J. Hortic. Sci. 2002, 8 , 7-10. [CrossRef]

27. Szalay, L. Comparison of flower bud development in almond, apricot and peach genotypes. Int. J. Hortic. Sci. 2006, 12, 93-98. [CrossRef]

28. Szalay, L. Development and cold hardiness of flower buds of stone fruits. In Morphology, Biology and Fertility of Flowers in Temperate Zone Fruits; Nyéki, J., Soltész, M., Szabó, Z., Eds.; Akadémiai Kiadó: Budapest, Hungary, 2008; pp. 63-82, ISBN 978-963-05-8591-0.

29. Szalay, L.; Timon, B.; Végvári, G. Modelling the phenological process of dormancy in frost-sensitive stone fruit species in the central part of the Carpathian Basin. Acta Hort 2008, 803, 117-122. [CrossRef] 
30. Szalay, L.; Froemel-Hajnal, V.; Bakos, J.; Ladányi, M. Changes of the microsporogenesis process and blooming time of three apricot genotypes (Prunus armeniaca L.) in Central Hungary based on long-term observation (1994-2018). Sci. Hortic. 2019, 246, 279-288. [CrossRef]

31. Cirilli, M.; Gattolin, S.; Chiozzotto, R.; Baccichet, I.; Pascal, T.; Quilot-Turion, B.; Rossini, L.; Bassi, D. The Di2/pet variant in PETALOSA gene underlies a major heat requirement-related QTL for blooming date in peach (P. persica L. Batsch). Plant Cell Physiol. 2021, 62, 356-365. [CrossRef]

32. Leida, C.; Terol, J.; Martí, G.; Agustí, M.; Llácer, G.; Badenes, M.L.; Ríos, G. Identification of genes associated with bud dormancy release in Prunus persica by suppression subtractive hybridization. Tree Physiol. 2010, 30, 655-666. [CrossRef] [PubMed]

33. Castède, S.; Campoy, J.A.; Le Dantec, L.; Quero-García, J.; Barreneche, T.; Wenden, B.; Dirlewanger, E. Mapping of candidate genes involved in bud dormancy and flowering time in sweet cherry (Prunus avium). PLoS ONE 2015, 10, e0143250. [CrossRef]

34. Chen, M.; Liu, X.; Huan, L.; Sun, M.; Liu, L.; Chen, X.; Li, L. Genome-wide analysis of Dof family genes and their expression during bud dormancy in peach (Prunus persica). Sci. Hortic. 2017, 214, 18-26. [CrossRef]

35. Wells, C.E.; Vendramin, E.; Tarodo, S.J.; Verde, I.; Bielenberg, D.G. A genome-wide analysis of MADS-box genes in peach [Prunus persica (L.) Batsch]. BMC Plant Biol. 2015, 15, 41. [CrossRef]

36. Tuan, P.A.; Bai, S.; Saito, T.; Ito, A.; Moriguchi, T. Dormancy-Associated MADS-Box (DAM) and the abscisic acid pathway regulate pear endodormancy through a feedback mechanism. Plant Cell Physiol. 2017, 58, 1378-1390. [CrossRef]

37. Yang, Q.; Gao, Y.; Wu, X.; Moriguchi, T.; Bai, S.; Teng, Y. Bud endodormancy in deciduous fruit trees: Advances and prospects. Hortic. Res. 2021, 8, 1-11. [CrossRef]

38. Yamane, H.; Ooka, T.; Jotatsu, H.; Hosaka, Y.; Sasaki, R.; Tao, R. Expressional regulation of PpDAM5 and PpDAM6, peach (Prunus persica) dormancy-associated MADS-box genes, by low temperature and dormancy-breaking reagent treatment. J. Exp. Bot. 2011, 62, 3481-3488. [CrossRef]

39. Balogh, E.; Halász, J.; Soltész, A.; Erôs-Honti, Z.; Gutermuth, A.; Szalay, L.; Höhn, M.; Vágujfalvi, A.; Galiba, G.; Hegedús, A. Identification, structural and functional characterization of dormancy regulator genes in apricot (Prunus armeniaca L.). Front. Plant Sci. 2019, 10, 402. [CrossRef]

40. Kitamura, Y.; Takeuchi, T.; Yamane, H.; Tao, R. Simultaneous down-regulation of DORMANCY-ASSOCIATED MADS-box6 and SOC1 during dormancy release in Japanese apricot (Prunus mume) flower buds. J. Hortic. Sci. Biotechnol. 2016, 91, 476-482. [CrossRef]

41. Wang, J.; Gao, Z.; Li, H.; Jiu, S.; Qu, Y.; Wang, L.; Ma, C.; Xu, W.; Wang, S.; Zhang, C. Dormancy-associated MADS-Box (DAM) genes influence chilling requirement of sweet cherries and co-regulate flower development with SOC1 gene. Int. J. Mol. Sci. 2020, 21, 921. [CrossRef]

42. Nakamura, T.; Song, I.J.; Fukuda, T.; Yokoyama, J.; Maki, M.; Ochiai, T.; Kameya, T.; Kanno, A. Characterization of TrcMADS1 gene of Trillium camtschatcense (Trilliaceae) reveals functional evolution of the SOC1/TM3-like gene family. J. Plant Res. 2005, 118, 229-234. [CrossRef]

43. Zhang, Y.; Li, Y.; Zhang, Y.; Guan, S.; Liu, C.; Zheng, G.; Gai, S. Isolation and characterization of a SOC1-Like gene from tree peony (Paeonia suffruticosa). Plant Mol. Biol. Report. 2015, 33, 855-866. [CrossRef]

44. Trainin, T.; Bar-Ya'akov, I.; Holland, D. ParSOC1, a MADS-box gene closely related to Arabidopsis AGL20/SOC1, is expressed in apricot leaves in a diurnal manner and is linked with chilling requirements for dormancy break. Tree Genet. Genomes 2013, 9 , 753-766. [CrossRef]

45. Martínez-Gómez, P.; Sozzi, G.O.; Sánchez-Pérez, R.; Rubio, M.; Gradziel, T.M. New approaches to Prunus tree crop breeding. J. Food Agric. Environ. 2003, 1, 52-63.

46. Timon, B. Öszibarack; Mezőgazda Kiadó: Budapest, Hungary, 2000.

47. Meier, U. Growth stages of mono- and dicotyledonous plants. In BBCH Monograph, 2nd ed.; Federal Biological Research Centre for Agriculture and Forestry: Berlin, Germany, 2001.

48. Morgulis, A.; Coulouris, G.; Raytselis, Y.; Madden, T.L.; Agarwala, R.; Schaffer, A.A. Database indexing for production. MegaBLAST searches. Bioinformatics 2008, 15, 1757-1764. [CrossRef] [PubMed]

49. Thompson, J.D.; Higgins, D.G.; Gibson, T.J. CLUSTAL W: Improving the sensitivity of progressive multiple sequence alignment through sequence weighting, position-specific gap penalties and weight matrix choice. Nucleic Acids Res. 1994, 22, 4673-4680. [CrossRef] [PubMed]

50. Tamura, K.; Peterson, D.; Peterson, N.; Stecher, G.; Nei, M.; Kumar, S. MEGA5: Molecular evolutionary genetics analysis using maximum likelihood, evolutionary distance, and maximum parsimony methods. Mol. Biol. Evol. 2011, 28, 2731-2739. [CrossRef] [PubMed]

51. Hall, T.A. BioEdit: A user-friendly biological sequence alignment editor and analysis program for Windows 95/98/ NT. Nucl. Acids Symp. Ser. 1999, 41, 95-98.

52. Maulión, E.; Valentini, G.H.; Kovalevski, L.; Prunello, M.; Monti, L.L.; Daorden, M.E.; Cervigni, G.D.L. Comparison of methods for estimation of chilling and heat requirements of nectarine and peach genotypes for flowering. Sci. Hortic. 2014, 177, 112-117. [CrossRef]

53. Viti, R.; Andreini, L.; Ruiz, D.; Egea, J.; Bartolini, S.; Iacona, C.; Campoy, J.A. Effect of climatic conditions on the overcoming of dormancy in apricot flower buds in two Mediterranean areas: Murcia (Spain) and Tuscany (Italy). Sci. Hortic. 2010, 124, 217-224. [CrossRef] 
54. Horsáková, J.; Krska, B. Evaluation of the course of microsporogenesis in some selected peach (Prunus persica L./Batsch) cultivars. Acta Agric. Serbica 2014, 37, 27-39. [CrossRef]

55. Castède, S.; Campoy, J.A.; García, J.Q.; Dantec, L.; Lafargue, M.; Barreneche, T.; Wenden, B.; Dirlewanger, E. Genetic determinism of phenological traits highly affected by climate change in Prunus avium: Flowering date dissected into chilling and heat requirements. New Phytol. 2014, 202, 703-715. [CrossRef] [PubMed]

56. Hajnal, V.; Zarif, O.; Ladanyi, M.; Tóth, M.; Szalay, L. Microsporogenesis of Apricot Cultivars in Hungary. Not. Bot. Horti Agrobot. Cluj-Napoca 2013, 41, 434-439. [CrossRef]

57. Salama, A.M.; Ezzat, A.; El-Ramady, H.; Alam-Eldein, S.M.; Okba, S.K.; Elmenofy, H.M.; Hassan, I.F.; Illés, A.; Holb, I.J. Temperate fruit trees under climate change: Challenges for dormancy and chilling requirements in warm winter regions. Horticulture 2021, 7, 86. [CrossRef]

58. Olukolu, B.A.; Trainin, T.; Fan, S.; Kole, C.; Bielenberg, D.G.; Reighard, G.L.; Abbott, A.G.; Holland, D. Genetic linkage mapping for molecular dissection of chilling requirement and budbreak in apricot (Prunus armeniaca L.). Genome 2009, 52, 819-828. [CrossRef]

59. Verde, I.; Abbott, A.G.; Scalabrin, S.; Jung, S.; Shu, S.; Marroni, F.; Rokhsar, D.S. The high-quality draft genome of peach (Prunus persica) identifies unique patterns of genetic diversity, domestication and genome evolution. Nat. Genet. 2013, 45, 487-494. [CrossRef]

60. Tao, R.; Watari, A.; Hanada, T.; Habu, T.; Yaegaki, H.; Yamaguchi, M.; Yamane, H. Self-compatible peach (Prunus persica) has mutant versions of the $\mathrm{S}$ haplotypes found in self-incompatible Prunus species. Plant Mol. Biol. 2007, 63, 109-123. [CrossRef]

61. Hegedûs, A.; Lénárt, J.; Halász, J. Sexual incompatibility in Rosaceae fruit tree species: Molecular interactions and evolutionary dynamics. Biol. Plant. 2012, 56, 201-209. [CrossRef]

62. Martínez-Gómez, P.; Arulsekar, S.; Potter, D.; Gradziel, T.M. An extended interspecific gene pool available to peach and almond breeding as characterized using simple sequence repeat (SSR) markers. Euphytica 2003, 131, 313-322. [CrossRef]

63. Immink, R.G.; Posé, D.; Ferrario, S.; Ott, F.; Kaufmann, K.; Valentim, F.L.; de Folter, S.; van der Wal, F.; van Dijk, A.D.; Schmid, M.; et al. Characterization of SOC1's central role in flowering by the identification of its upstream and downstream regulators. Plant Physiol. 2012, 160, 433-449. [CrossRef] [PubMed] 